\title{
Reversal of Multicellular-form Development in a Conditional Morphological Mutant of the Fungus Wangiella dermatitidis
}

\author{
By CHARLES W. JACOBS, $\dagger$ ROWENA L. ROBERTS $\ddagger$ AND \\ PAUL J. SZANISZLO* \\ Department of Microbiology and Center for Applied Microbiology, University of Texas, Austin, \\ Texas 78712-1095, USA
}

(Received 22 November 1984 ; revised 5 February 1985)

\begin{abstract}
Yeast cells of the temperature-sensitive morphological mutant strain Mc3 of the polymorphic fungus Wangiella dermatitidis were allowed to initiate multicellular-form development at the restrictive temperature $\left(37^{\circ} \mathrm{C}\right)$, then induced to resume budding yeast growth by downshift to the permissive temperature $\left(25^{\circ} \mathrm{C}\right)$. The kinetics of the resumption of yeast budding were investigated, and the dependence of bud initiation upon DNA synthesis, protein synthesis and microtubule function was probed. The results indicated that the thermolabile event in strain Mc3 was a cell cycle event involved in yeast budding, and that developing multicellular forms retained most of the machinery necessary to reinitiate budding. However, initiation of budding required the synthesis of protein, and possibly RNA, suggesting that one or more proteins involved in initiation of budding were not present in the developing multicellular forms.
\end{abstract}

\section{INTRODUCTION}

Temperature-sensitive multicellular mutants of the polymorphic fungus Wangiella dermatitidis grow as unicellular budding yeasts at $25^{\circ} \mathrm{C}$, but rapidly and quantitatively initiate multicellular-form development when incubated at $37^{\circ} \mathrm{C}$ (Roberts \& Szaniszlo, 1978). In contrast, the wild-type strain grows as a yeast at either temperature. The development of multicellular forms from yeasts is a vegetative growth process that results from a block in the yeast cell cycle (Roberts \& Szaniszlo, 1980; Jacobs \& Szaniszlo, 1982). This cell cycle block initiates a series of events that includes cessation of bud formation, isotropic growth, continued nuclear division within the enlarged cell, and subsequent formation of transverse septa (Szaniszlo et al., 1983b). Morphological development is also accompanied by significant alterations in the quantities of cell wall glucans, mannans and chitin, and in their distributions in the cell wall (Szaniszlo et al., 1983a).

The developmental sequence leading to the formation of multicellular units represents a morphological alternative to hyphal or yeast growth. Multicellular-form development can be induced in wild-type strains during establishment of lesions in natural infections in humans (McGinnis, 1983), or in experimental infections in mice (Nishimura \& Miyaji, 1983). It can also be induced in experimental cultures by incubation of yeast cells in liquid medium at low $\mathrm{pH}$ (Szaniszlo et al., 1976) or by incubation on solid medium for prolonged times (Szaniszlo et al., 1976). The regulation of expression between yeast and multicellular alternatives is determined by at least two genes, $m \mathrm{~cm} 2$ and $m \mathrm{~cm} 3$, as shown by analysis of temperature-sensitive multicellular mutants (R. C. Schafer, C. R. Cooper \& P. J. Szaniszlo, unpublished data).

$\dagger$ Present address: Division of Biological Sciences, University of Michigan, Ann Arbor, MI 48109, USA.

$\ddagger$ Present address: W. R. Grace and Co., Columbia, MD 21044, USA.

Abbreviation: HU, hydroxyurea. 
Furthermore, a critical point for the regulation of morphological alternatives seems to occur in early G2 phase of the yeast cell cycle, shortly before bud emergence, since the execution points of strains $\mathrm{Mc} 2(\mathrm{mcm} 2)$ and $\mathrm{Mc} 3(\mathrm{mcm} 3)$ occur during this time (Jacobs \& Szaniszlo, 1982).

Because multicellular-form development and budding represent two alternative developmental pathways, we investigated the regulation of commitment to these pathways. Earlier studies were focused on the transition from the yeast phase to the multicellular form. This study addressed the events occurring during the initial stages of multicellular-form development and the transition from this early stage to the yeast phase. Multicellular form-development in wildtype cells can be reversed via budding in cells that are before an unidentified step in development, or by hyphal outgrowth in cells that are beyond that step (Oujezdsky et al., 1973). However, in this study the early phase of multicellular-form development was induced by incubation of strain $\mathrm{Mc} 3$ at $37^{\circ} \mathrm{C}$, then budding growth was allowed to resume by shifting the cells to $25^{\circ} \mathrm{C}$. The effects of several inhibitors of basic cellular functions on reinitiation of budding were also studied. The mutant strain $\mathrm{Mc3}$, carrying the mutant gene $\mathrm{mcm} 3$, was used because it exhibits first-cycle commitment to multicellular-form development and does not exhibit significant lethality at $37^{\circ} \mathrm{C}$ (Roberts \& Szaniszlo, 1978). The use of the mutant allowed study of a phenomenon that occurs less quantitatively and with less synchronicity in the wildtype strain (K. B. Oujezdsky \& P. J. Szaniszlo, unpublished data).

Based on the results presented here, the development of multicellular forms from yeasts appears not only to be a cell cycle related event, but also one in which the developing forms are blocked near the thermolabile event in strain Mc3. Reinitiation of yeast budding was not blocked by inhibitors of DNA synthesis or microtubule function, but was blocked by the protein synthesis inhibitor cycloheximide.

\section{METHODS}

Organism, media and culture conditions. The temperature-sensitive morphological mutant strain Mc3 (ATCC 34716), derived from the wild-type Wangiella dermatitidis strain ATCC 34100, has been previously described (Roberts \& Szaniszlo, 1978; Roberts et al., 1979; Jacobs \& Szaniszlo, 1982). Cells were maintained and experiments were done in CDY broth (Roberts \& Szaniszlo, 1978). Cultures were grown at either $25^{\circ} \mathrm{C}$ or $37^{\circ} \mathrm{C}$, with shaking at 250 r.p.m. as described previously (Roberts \& Szaniszlo, 1978). Inocula were standardized by harvesting 24-h-old, mid-exponential phase cultures grown to a density of about $5 \times 10^{6} \mathrm{cells} \mathrm{ml}^{-1}(\mathrm{Jacobs} \&$ Szaniszlo, 1982). Incubation at $37^{\circ} \mathrm{C}$ was for either 6 or $12 \mathrm{~h}$, as indicated for each experiment; the duration of incubation within these time limits did not affect the outcome of the experiments. The DNA synthesis inhibitor hydroxyurea was added to CDY broth as powder to a final concentration of $0.1 \mathrm{M}$ (Roberts et al., 1980). Cycloheximide was first dissolved in acetone to a concentration of $100 \mathrm{mg} \mathrm{ml}^{-1}$, and then the solution was added to $\mathrm{CDY}$ broth to a final concentration of $50 \mu \mathrm{g}$ cycloheximide $\mathrm{ml}^{-1}$. The microtubule inhibitor nocodazole was added as a solution in dimethyl sulphoxide (Jacobs \& Szaniszlo, 1982) to a final inhibitor concentration of $10 \mu \mathrm{g} \mathrm{m}^{-1}$ and a final DMSO concentration of $1 \%(\mathrm{v} / \mathrm{v})$. At this concentration, DMSO had no noticeable effect on cell division, cell morphology, budding, macromolecular synthesis or multicellular-form development relative to cells grown in CDY broth without DMSO (Jacobs \& Szaniszlo, 1982). Shifts of cells to $25^{\circ} \mathrm{C}$ after incubation for 6 or $12 \mathrm{~h}$ at $37^{\circ} \mathrm{C}$ were accomplished by rapid centrifugation of cells and resuspension into fresh medium; the procedure used here required less than $2 \mathrm{~min}$. Preliminary experiments indicated that centrifugation did' not perturb cell growth or budding relative to cultures that were shifted to fresh medium by dilution of the original culture.

Measurement of cell parameters. Population density was monitored using a model $\mathrm{Z}_{\mathrm{B}}$ Coulter Counter (Roberts et $a l ., 1980$ ). Nuclei were visualized with the dye mithramycin and fluorescence microscopy as described by Jacobs $\&$ Szaniszlo (1982). Morphology was determined by phase-contrast microscopy. Cells were classified according to nuclear and budded conditions by the criteria of Roberts et al. (1980). Type I cells are unbudded with a single nucleus; type II cells are budded with a nucleus in the mother cell; type III cells are budded with an elongated nucleus in the mother cell-bud neck; and type IV cells are budded with one nucleus in the mother cell and one in the bud. The results presented are the mean values obtained from at least two independent experiments; the results of each independent experiment were the mean of values obtained from duplicate or triplicate cultures grown from the same inoculum and incubated under identical conditions.

Chemicals. Hydroxyurea, cycloheximide and nocodazole were purchased from Sigma. Mithramycin was a gift of Pfizer. Calcofluor was a gift of American Cyanamid, Bound Brook, NJ, USA. 
RESULTS

\section{Resumption of bud formation upon shift from $37^{\circ} \mathrm{C}$ to $25^{\circ} \mathrm{C}$}

Preliminary experiments indicated that populations of strain $\mathrm{Mc} 3$ incubated at $37^{\circ} \mathrm{C}$ for increasing durations, to induce increasing degrees of multicellular-form development, required correspondingly longer times to initiate budding upon return to fresh medium at $25^{\circ} \mathrm{C}$ (Table 1 ). In subsequent experiments, populations of cells that had begun early multicellular-form development were generated by growth of strain $\mathrm{Mc} 3$ at $37^{\circ} \mathrm{C}$ for 6 or $12 \mathrm{~h}$. Resulting populations consisted of more than $80 \%$ unbudded, type I cells (Fig. $1 \mathrm{~b}$ ). When these cells were then shifted to $25{ }^{\circ} \mathrm{C}$ in fresh CDY broth, budded cells accounted for about $60 \%$ of the population within $1 \mathrm{~h}$ after downshift; most of these cells were type II (Fig. $1 c$ ). The populations of type II cells declined and those of type IV (and probably type III, but the percentages are small) cells increased by $2 \mathrm{~h}$ after downshift (Fig. $1 c, d$ ). The increase in type I cells and the decrease in type IV cells that occurred by $3 \mathrm{~h}$ at $25^{\circ} \mathrm{C}$ (Fig. $1 b, d$ ) correlated very well with the onset of increase in cell number (Fig. $1 a$ ). Since budding in yeast cells is not dependent upon completion of DNA synthesis (Roberts \& Szaniszlo, 1980), we asked whether resumption of bud formation was dependent on completion of DNA synthesis. Cells simultaneously blocked in the budding cycle by incubation at $37^{\circ} \mathrm{C}$ and in the nuclear division cycle by the DNA synthesis inhibitor hydroxyurea (HU), then downshifted into medium without $\mathrm{HU}$, behaved similarly to cells grown in the absence of the inhibitor (Fig. $l e, f, g, h)$. The maximum percentages of each cell type occurred sequentially (Fig. $1 f, g, h$ ), and the time of increase in cell number (about 4$5 \mathrm{~h}$ after downshift) coincided with increases in the percentage of unbudded cells (Fig. $1 e, f$ ). The behaviour of the HU-treated cells differed from that of the control cells in two respects. First, resumption of budding growth by the treated cells occurred only after a considerably longer lag (Fig. 1e), and the increase in percentage of type II cells was not observed until $3 \mathrm{~h}$ after downshift (Fig. 1g). Second, the treated cells exhibited a pronounced increase in the percentage of type III cells $4 \mathrm{~h}$ after downshift (Fig. $1 h$ ).

\section{Inhibition of the reinitiation of budding growth}

When cells of strain Mc3 were pregrown at $37^{\circ} \mathrm{C}$ in the presence of $\mathrm{HU}$ to arrest both bud emergence and nuclear division, and were then downshifted into the presence of $\mathrm{HU}$, cell division was inhibited for at least 12 h (Fig. $2 a$ ), and only about $10 \%$ of the cells initiated buds (Fig. $2 b$ ). These two effects did not occur if cells were grown in CDY broth without HU before downshift into CDY broth with HU (Fig. $2 c, d$ ). Although the primary effect of HU is to block DNA synthesis, exposure to $\mathrm{HU}$ for more than about $6 \mathrm{~h}$ inhibits protein synthesis (Roberts \& Szaniszlo, 1980). Thus, the inability to reinitiate budding could have been caused by a block of protein synthesis. We tested this hypothesis by evaluating the effect of the protein synthesis inhibitor cycloheximide on bud initiation. In populations shifted from $37^{\circ} \mathrm{C}$ in the presence of $\mathrm{HU}$ to $25^{\circ} \mathrm{C}$ in the presence of cycloheximide, neither cell division nor a redistribution of cells

Table 1. Resumption of budding by cells of strain Mc3 after various degrees of multicellular-form development induced by incubation at $37^{\circ} \mathrm{C}$

\begin{tabular}{|c|c|c|c|c|}
\hline $\begin{array}{l}\text { Duration of incubation } \\
\text { at } 37^{\circ} \mathrm{C}(\mathrm{h}) \ldots \\
\text { Morphology of cells } \\
\text { at time of shift to } 25^{\circ} \mathrm{C} \ldots\end{array}$ & $\begin{array}{c}12 \\
\text { Enlarged, } \\
\text { unbudded }\end{array}$ & $\begin{array}{c}24 \\
\text { Enlarged, minority } \\
\text { of cells with } \\
\text { internal septa }\end{array}$ & $\begin{array}{c}36 \\
\text { Enlarged, majority } \\
\text { of cells with } \\
\text { internal septa }\end{array}$ & $\begin{array}{l}\quad 48 \\
\text { Enlarged, } 90 \% \\
\text { of cells with } \\
\text { internal septa }\end{array}$ \\
\hline $\begin{array}{l}\text { Duration of incubation } \\
\text { at } 25^{\circ} \mathrm{C}(\mathrm{h})\end{array}$ & \multicolumn{4}{|c|}{ Percentage of population with buds } \\
\hline 0 & 5 & 0 & 0 & 0 \\
\hline 3 & $85^{*}+$ & 10 & 2 & 8 \\
\hline 6 & $75 \dagger$ & 35 & 8 & 11 \\
\hline 12 & $30 \dagger$ & $80^{*} \dagger$ & 30 & 18 \\
\hline
\end{tabular}




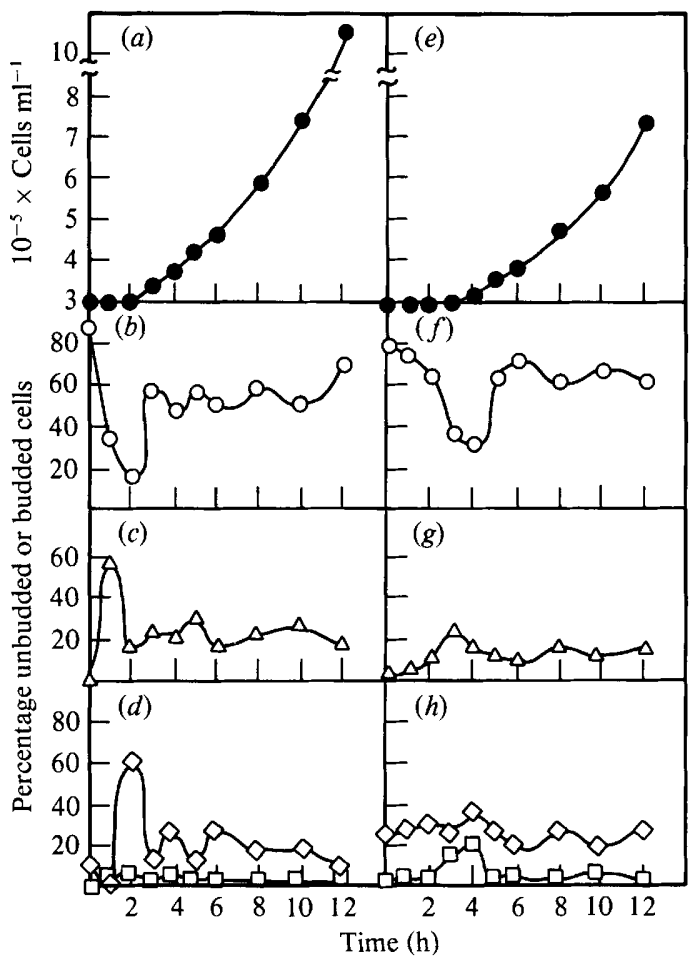

Fig. 1. Effect of shift from $37^{\circ} \mathrm{C}$ to $25^{\circ} \mathrm{C}$ on cell populations of strain $\mathrm{Mc} 3$ preincubated at $37^{\circ} \mathrm{C}(a, b$, $c, d)$ in the absence of $\mathrm{HU}$ and those preincubated at $37^{\circ} \mathrm{C}$ in the presence of $0 \cdot 1 \mathrm{M}-\mathrm{HU}(e, f, g, h)$. Population growth ( $a$ and $e$ ), and the proportions of unbudded, uninucleate (type I) cells $(b$ and $f$ ) and of budded cell types $(c, d, g, h)$ were measured: $O$, type I, unbudded; $\triangle$, type II, budded premitotic; $\square$, type III, budded mitotic; $\diamond$, type IV, budded postmitotic. Temperature shifts were accomplished by harvesting cells grown for $6 \mathrm{~h}$ at $37^{\circ} \mathrm{C}$ by rapid centrifugation and then resuspending them immediately in appropriate fresh medium that had been equilibrated to $25^{\circ} \mathrm{C}$.

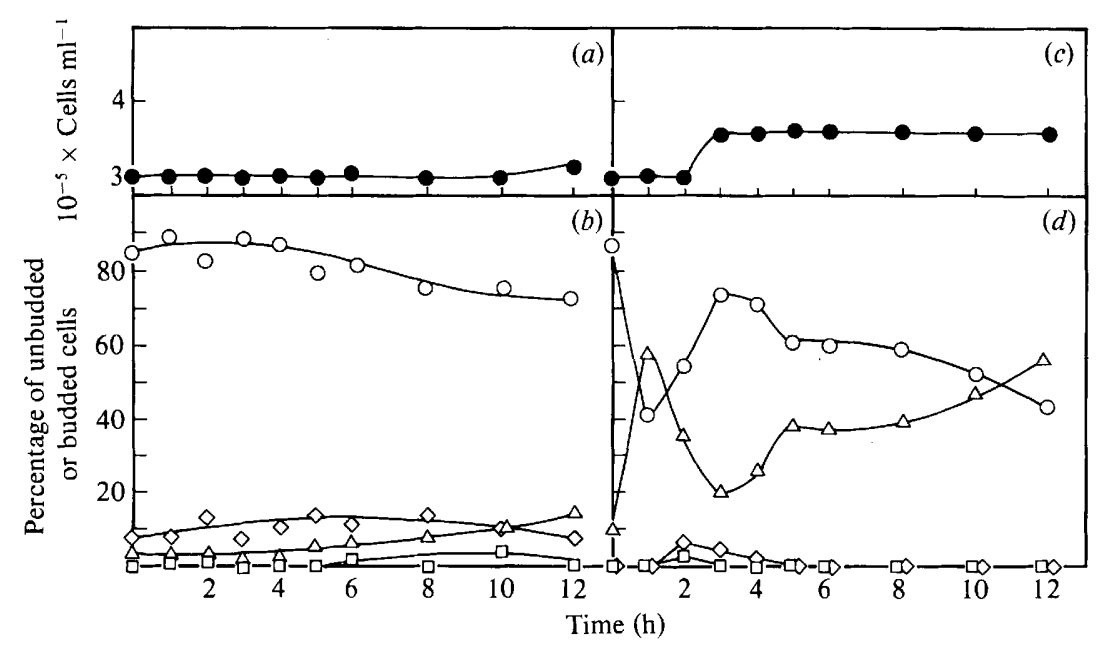

Fig. 2. Effect of shift of strain Mc3 cells from $37^{\circ} \mathrm{C}$ in the presence of $\mathrm{HU}$ to $25^{\circ} \mathrm{C}$ in the presence of $\mathrm{HU}$ on the population (a) and cell type distribution (b), and of shift from $37^{\circ} \mathrm{C}$ in the absence of $\mathrm{HU}$ to $25^{\circ} \mathrm{C}$ in the presence of $\mathrm{HU}$ on population $(c)$ and cell type distribution $(d)$. Symbols are as in Fig. 1. The temperature shift was accomplished as described for Fig. 1. 


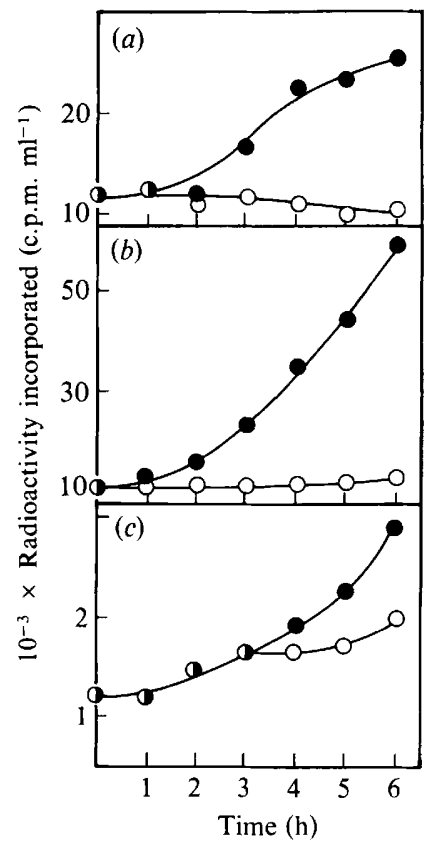

Fig. 3

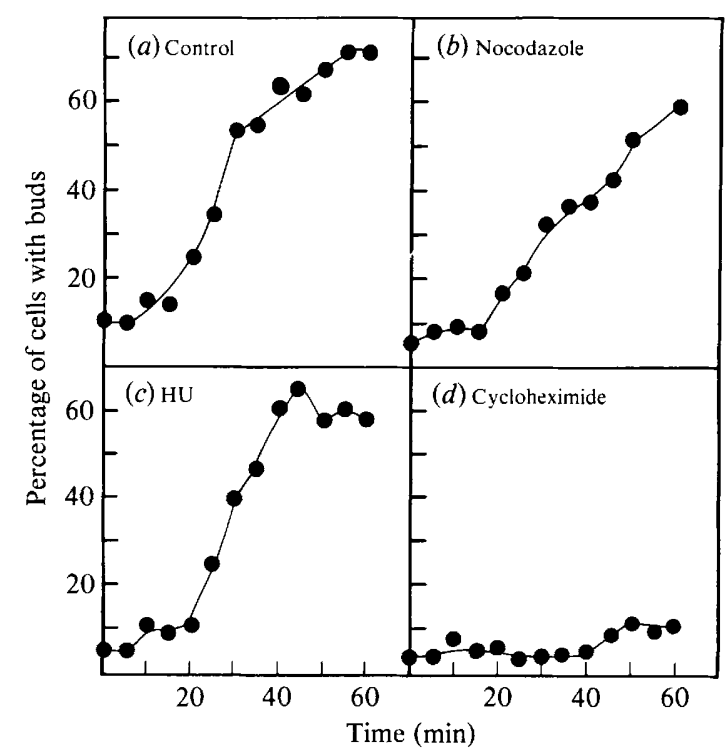

Fig. 4

Fig. 3. Effect of cycloheximide on macromolecular synthesis during shift from $37^{\circ} \mathrm{C}$ to $25^{\circ} \mathrm{C}$. Strain $\mathrm{Mc} 3$ cells pregrown for $6 \mathrm{~h}$ at $37^{\circ} \mathrm{C}$ in $\mathrm{CDY}$ broth without cycloheximide were harvested by centrifugation and resuspended in an equal volume of fresh CDY broth (O) or CDY broth plus cycloheximide $(O)$. The amount of $\left[{ }^{3} \mathrm{H}\right]$ leucine $(a)$ incorporated into protein and of $\left[{ }^{14} \mathrm{C}\right]$ adenine incorporated into RNA $(b)$ and DNA $(c)$ was measured at the indicated times as described by Roberts \& Szaniszlo (1978). The cycloheximide was added to the experimental cultures as an acetone solution; control cultures contained the same concentration of acetone but no cycloheximide.

Fig. 4. Percentage of cell population of strain Mc3 with buds (type II cells) during the 60 min period following shift from growth at $37^{\circ} \mathrm{C}$ for $6 \mathrm{~h}$ in CDY broth to growth at $25^{\circ} \mathrm{C}$ in CDY broth (a) or CDY broth with nocodazole $(b)$, hydroxyurea (HU) $(c)$ or cycloheximide $(d)$. Cells were harvested at the indicated times by rapid centrifugation and fixed in ethanol/acetone $(1: 1, v / v)$ within 2 min of removal from the culture.

within the cell cycle occurred (data not shown, but similar to Fig. $2 a, b$ ). The results were the same when uninhibited cells were downshifted into medium with cycloheximide (data not shown). In the latter experiments, cycloheximide inhibited the net synthesis of protein (Fig. $3 a$ ) and RNA (Fig. $3 b$ ) for at least $6 \mathrm{~h}$ after downshift into medium containing cycloheximide. To a lesser degree, net DNA synthesis was also inhibited (Fig. 3c). In these experiments, the medium initially contained, in addition to cycloheximide, $0.4 \mathrm{mg}$ acetone $\mathrm{ml}^{-1}$. The control cultures containing this concentration of acetone appeared to behave identically to cultures grown in CDY alone.

\section{Kinetics of budding at very early times}

Bud initiation began between 15 and 20 min after cells, pregrown at $37^{\circ} \mathrm{C}$ in CDY broth, were downshifted into the same medium, or into medium with the microtubule inhibitor nocodazole, and between 20 and $25 \mathrm{~min}$ after downshift into medium with $\mathrm{HU}$ (Fig. $4 a, b, c$ ). Maximum percentages of budded cells were observed $50 \mathrm{~min}$ after downshift into CDY broth (Fig. $4 a$ ), and 45 min after downshift into medium with HU (Fig. $4 c$ ). No clear maximum was observed in the presence of nocodazole, but $60 \%$ of the cells were budded after $60 \mathrm{~min}$ (Fig. $4 \mathrm{~b}$ ). Half-maximal levels of budding were observed within 5-10 min of bud initiation (or about 25-30 min after downshift) in CDY broth with or without inhibitors. The increased percentages of budded cells were accompanied by decreased percentages of unbudded cells in the absence of cell division 
Table 2. Mean times of initial appearance of buds and maximum percentages of budded cells when subpopulations of initially uninucleate and binucleate cells were downshifted into various media

The times of bud emergence (expressed as min after downshift) and the percentages of budded cells for each medium are means derived from three replicate experiments. In each experiment, samples were removed from duplicate cultures at $5 \mathrm{~min}$ intervals and fixed with formaldehyde. At least 200 cells from each of the duplicate samples were scored at $630 \times$ magnification for the presence of buds, using phasecontrast optics.

\begin{tabular}{ccccc} 
Medium* & \multicolumn{2}{c}{$\begin{array}{c}\text { Time of } \\
\text { initial bud appearance }\end{array}$} & $\overbrace{\text { Uninucleate }}^{\text {Max. percentage of buds }}$ & Binucleate \\
CDY & 17 & 23 & 55 & 49 \\
NOC & 17 & 30 & 34 & 48 \\
HU & 21 & 29 & 33 & 49
\end{tabular}

* CDY, CDY broth; NOC, CDY broth plus $1 \%$ DMSO and $10 \mu \mathrm{g}$ nocodazole $\mathrm{ml}^{-1}$; HU, CDY broth plus $0 \cdot 1 \mathrm{M}-\mathrm{HU}$.

and apparently resulted from budding of initially unbudded cells (data not shown). The initial percentages of mitotic cells (type III), and those with nuclei in both the mother cell and bud (type IV) did not change when cells were downshifted to medium with nocodazole (data not shown). Little change in the initial percentages of cell types was observed within 60 min of downshift into medium containing cycloheximide (Fig. 4d). Unbudded cells failed to form even rudimentary buds in the presence of this inhibitor, and no redistribution of cells within the budded cell types was detected. Although these results could indicate that the cells had been killed by incubation with cycloheximide, the cycloheximide inhibition was completely and quantitatively reversible after $60 \mathrm{~min}$, and cells so treated retained viability (data not shown).

\section{Kinetics of budding and degree of multicellular-form development}

Cells incubated for $12 \mathrm{~h}$ at $37^{\circ} \mathrm{C}$ generated two populations of enlarged, unbudded cells : those with a single nucleus and those with two or more nuclei. The times (after downshift to $25^{\circ} \mathrm{C}$ ) at which the multinucleate cells initiated budding consistently lagged 5-15 min behind the times at which uninucleate cells initiated budding (Table 2); the length of the lag depended on the conditions of incubation. Maximum percentages of uninucleate budded cells were observed between 30 and $35 \mathrm{~min}$ after downshift into the presence of either nocodazole or HU (where cell division was blocked), but were not reached until 55 min after downshift into CDY broth alone (where cell division and separation followed bud development). Maximum percentages of budded cells with two or more nuclei in the mother cell were observed about 48-49 min after downshift under all three culture conditions.

\section{Reinitiation of budding and distribution of cell wall polymers}

Buds that emerged from cells downshifted into CDY broth had considerably less affinity for calcofluor than did the mother cells (Fig. $5 a$ ) or cells that had not been downshifted (Fig. $5 d$ ), and the intensity of the stain resembled the general fluorescence of yeast cells grown at $25^{\circ} \mathrm{C}$ (Fig. $5 b, c$ ). The population regained its tendency to concentrate the dye at discrete loci within a few hours after downshift (Fig.6a), and preferential staining of the septal region became noticeable soon afterwards (Fig. $6 b$ ).

\section{DISCUSSION}

The results presented here indicated that cells early in multicellular-form development were blocked in the yeast budding cycle shortly before bud emergence and that they required some new protein synthesis to reinitiate budding. The observations supported the hypothesis that multicellular-form development resulted from inhibition of the budding cycle of the cell, without 

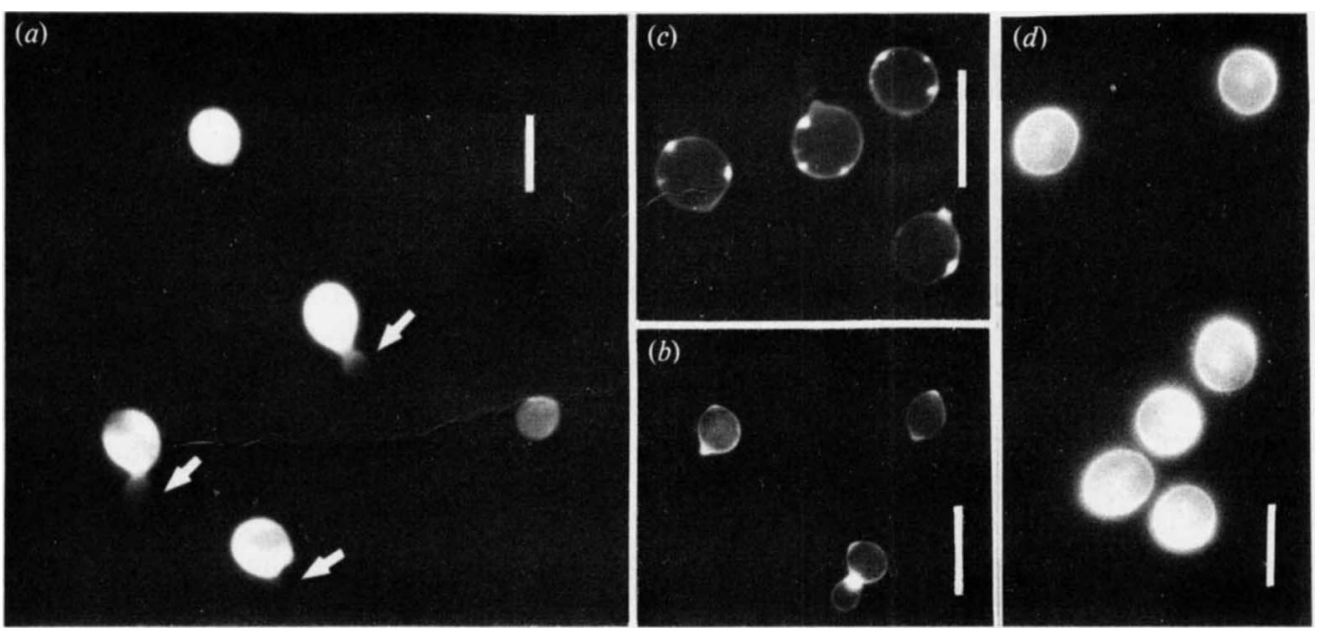

Fig. 5. Affinities of mother cells and newly emergent buds of strain Mc3 for the fluorescent dye calcofluor $(a)$. Cells were grown for $12 \mathrm{~h}$ at $37^{\circ} \mathrm{C}$, then shifted to $25^{\circ} \mathrm{C}$ for $30 \mathrm{~min}$. Arrows indicate nonfluorescent buds. Typical staining patterns of yeast cells grown at $25^{\circ} \mathrm{C}(b)$ and of stationary-phase yeasts $(c)$ indicate localization of calcofluor stain fluorescence at the mother cell-bud necks and bud and birth scars. $(d)$ Uniform staining pattern of developing multicellular forms grown for $12 \mathrm{~h}$ at $37^{\circ} \mathrm{C}$. Bars, $10 \mu \mathrm{m}$.

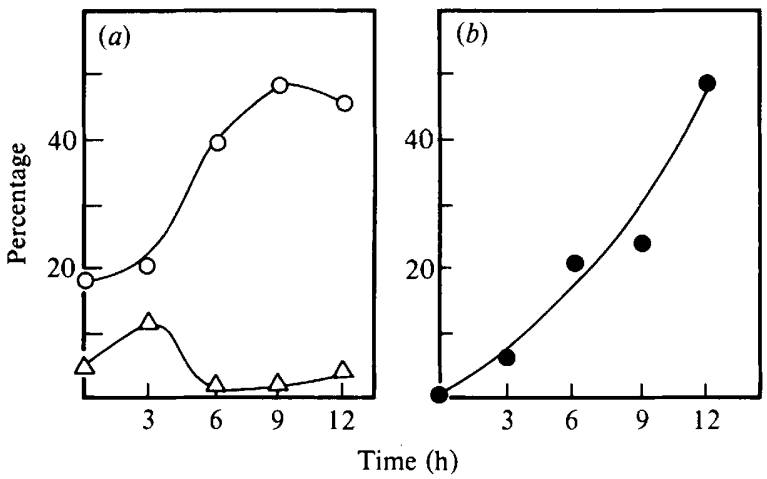

Fig. 6. Kinetics of relocalization of calcofluor-stained material after shift of strain Mc3 cells from growth for $12 \mathrm{~h}$ in $\mathrm{CDY}$ broth at $37^{\circ} \mathrm{C}$ to growth in CDY broth at $25^{\circ} \mathrm{C}$. (a) Percentage of cell population with one $(O)$ or two or more $(\triangle)$ brightly staining loci; $(b)$ percentage of budded cells with calcofluor-stained septa.

inhibiting cellular growth. They also suggested that a specific event in the budding cycle failed to function when cells of strain Mc3 were shifted to the restrictive temperature, but that the budding cycle was restored soon after the cells were returned to the permissive temperature.

The initial series of experiments, in which cultures were monitored for several hours after downshift (Fig. $1 a, b, c, d$ ), suggested that at $37^{\circ} \mathrm{C}$ the cells were blocked in the budding cycle and that nearly synchronous budding occurred when the cells were returned to $25^{\circ} \mathrm{C}$. These conclusions were confirmed in the experiments in which cells were monitored for $60 \mathrm{~min}$ immediately following downshift (Fig. 4a). In these experiments, uninucleate cells that had been incubated at $37^{\circ} \mathrm{C}$ recovered from the effects of the temperature shift, cell cycle block and initiation of multicellular-form development, and began to bud between 15 and 20 min after downshift; binucleate cells began to bud slightly later (Table 2). The delay in bud emergence by the binucleate cells possibly indicated that they were further along the pathway to multicellularform development than were the uninucleate cells. This was suggested by the observation that 
some cells of populations that were in advanced stages of multicellular-form development budded after the return to $25^{\circ} \mathrm{C}$, but did so slowly (Table 1). However, these experiments also indicated that neither uninucleate nor binucleate cells were simply unbudded yeast cells with an uncomplicated block in the budding pathway at the thermolabile event in the cell cycle of the mutant. Instead it appears that several developmental changes had occurred that differentiate these cells from yeasts. During early multicellular-form development, budding ceases, nuclear division is transiently inhibited (most of the cells were uninucleate after $12 \mathrm{~h}$ at $37^{\circ} \mathrm{C}$, during which time wild-type cultures would have passed through about four generations), cell growth switches to arithmetic (Jacobs \& Szaniszlo, 1985), cell volume increases due to isotropic growth (Roberts \& Szaniszlo, 1978; Jacobs \& Szaniszlo, 1985), and the composition and structural arrangement of the cell wall changes (Fig. 5; Cooper et al., 1984). Nevertheless, although the initial block seems to be in the budding cycle of the yeast cell, resulting in numerous changes, the cells that were downshifted had some substantial yeast characters, since they resumed budding very rapidly. The brief delay in budding probably reflected the time required for a cell to restore itself to a state in which it was competent to bud, in addition to completing the events blocked by failure of the thermolabile event.

The delay in budding, with respect to control cultures, by cells that had been treated with $\mathrm{HU}$ during incubation at $37^{\circ} \mathrm{C}$ (Fig. $1 f, g, h$ ), could have resulted because HU-treated cells, being blocked in $\mathrm{S}$ phase, arrested earlier in the budding cycle than did control cells. Alternatively, it could have resulted from nonspecific effects of the inhibitor. Although a major effect of $\mathrm{HU}$ is to block DNA synthesis by inhibiting ribonucleotide reductase, it has a number of other effects, not all of which are understood (Elford, 1968). Since bud initiation in cells preincubated at $37^{\circ} \mathrm{C}$ without $\mathrm{HU}$ was slightly delayed when they were downshifted into its presence (Fig. $4 c$ ) and since the initial effect of HU on the yeast phase is an accumulation of unbudded cells (Roberts \& Szaniszlo, 1980), the nonspecific effects of HU may have affected the budding process. Such nonspecific effects could also explain the inhibition of budding in the cells that were downshifted into the presence of HU (Fig. 2).

Although the microtubule inhibitor nocodazole did not block bud emergence upon cell downshift (Fig. 4b), it did prevent nuclear migration and nuclear division, just as it did in wildtype $W$. dermatitidis yeasts (Jacobs \& Szaniszlo, 1982). This observation indicated that budding during reversal of multicellular-form development was similar to yeast budding and does not depend on microtubule function.

Three results suggested that protein synthesis was necessary for the resumption of budding. First, untreated cells downshifted into the presence of cycloheximide failed to bud (Fig. $4 d$ ). Second, no budding was observed when cells treated with HU were downshifted into medium containing cycloheximide. Under the conditions we used, cycloheximide inhibited protein synthesis (Fig. $3 a$ ). The final result is less directly related to the argument, and could be subject to other interpretations, but budding in cells preincubated in medium with $\mathrm{HU}$ was inhibited when they were downshifted into medium with HU (Fig. 2b). Roberts \& Szaniszlo (1980) demonstrated that the primary effect of HU on $W$. dermatitidis is to block DNA synthesis, but yeast cells blocked in DNA synthesis by HU still bud. They also demonstrated that cells grown in the presence of $\mathrm{HU}$ for $6 \mathrm{~h}$ or longer seem to be blocked in protein synthesis. This secondary effect of HU seemed to be the most likely cause of the inhibition of budding, considering that the cells had been incubated for $12 \mathrm{~h}$ in the presence of $\mathrm{HU}$ before downshift, and that cycloheximide blocked bud emergence without immediately inhibiting DNA synthesis (Figs $3 c$ and $4 d$ ).

It is unlikely that cells treated with cycloheximide failed to bud because the cells were below a critical cell volume required for bud initiation, since after $12 \mathrm{~h}$ growth at $37^{\circ} \mathrm{C}$, the average cell volume of strain $\mathrm{Mc} 3$ is larger than $90 \%$ of the cells in an exponentially-growing population of yeasts (including cells with very large buds) (Jacobs \& Szaniszlo, 1985). Cycloheximide could have blocked bud initiation by a general block of protein synthesis, if the regulation of cellular volume was very sensitive to the intracellular protein concentration. At $1000 \times$ magnification, careful observation allows detection of emerging buds as minute irregularities on the cell surface before they have reached the point of being recognizable as buds. Small, abortive bud initials of 
this size were not observed in cycloheximide-treated cultures. It seems unlikely that the regulation of cellular volume could be so sensitive to the intracellular protein concentration that even the extremely small cytoplasmic volume required to fill an undetectable bud initial (far less than $1 \%$ of the total cell volume) would lower the intracellular protein concentration enough to block cellular growth. It is more probable that cycloheximide blocked the synthesis of at least one protein, not present at the time of shift from $37^{\circ} \mathrm{C}$ to $25^{\circ} \mathrm{C}$, that was necessary for bud initiation. Such a protein could be one directly involved in bud initiation, or one necessary for recovery of the cells from the incubation at $37^{\circ} \mathrm{C}$ and the subsequent temperature shift.

The inhibition of RNA synthesis by cycloheximide (Fig. $3 b$ ) was probably due to a primary effect on ribosomal RNA synthesis that occurred very soon after addition of the drug and, later, by a secondary effect on mRNA synthesis induced by the block of protein synthesis. In many fungi, cycloheximide seems to have a direct, specific and immediate inhibitory effect on rRNA synthesis while transcription of mRNA is not affected (DeKloet, 1966; Fiala \& Davis, 1965; Fukuhara, 1965; Haidle \& Storck, 1966; Horgen \& Griffin, 1971; Taber \& Vincent, 1969; Timberlake \& Griffin, 1974). The block of protein synthesis in most of the fungi considered in these studies is also complete within $2-5 \mathrm{~min}$ after addition of cycloheximide. Therefore, although bulk mRNA synthesis seems to continue in the presence of cycloheximide, the transcription of specific mRNAs whose transcription is mediated by positive regulatory proteins could be blocked if the positive regulatory proteins were not synthesized. In this study, cycloheximide could have blocked bud emergence by a primary effect on synthesis of proteins from pre-existing mRNAs, or by a secondary effect of blocking transcription of specific mRNAs which blocked synthesis of their specific regulatory proteins after downshift. Preliminary experiments with $\alpha$-amanitin, which inhibits mRNA synthesis in many organisms, have suggested that mRNA must be transcribed before bud initiation (C. W. Jacobs \& P. J. Szaniszlo, unpublished data).

It seems that developing multicellular forms lack at least one protein required for budding. The absence of the protein(s) could be explained in either of two ways. First, it may have been present in the active form in the inoculum yeasts, and then degraded or otherwise inactivated during the incubation at $37^{\circ} \mathrm{C}$. Second, its synthesis or activation may have been under cell cycle control and blocked by dysfunction of the thermolabile event at the restrictive temperature. Detection and analysis of the $\mathrm{mcm} 3$ gene product may help to shed light on this interesting developmental question.

The reorganization of nascent cell wall polymers into configurations characteristic of yeasts occurred rapidly (Figs 5 and 6), as revealed by calcofluor-staining patterns. Just as the delocalization and intensification of calcofluor stain occur rapidly upon induction of multicellular-form development (Cooper et al., 1984; C. W. Jacobs, C. R. Cooper \& P. J. Szaniszlo, unpublished data), relocalization of the stain to the mother cell-bud junction (Fig. 6) and lessening of its intensity in the nascent cell wall (Fig. 5) seemed to be characteristic of reinitiation of budding.

The results of these investigations indicated that regulation of morphology was dependent upon more than rearrangement of cell wall polymers. The evidence indicated that most, but not all, of the machinery necessary for budding was present in the developing multicellular forms. Thus, even the relatively simple form of cellular differentiation represented by multicellularform development required more than simple reorientation of the growth processes of the cell. Rather, it demanded an active commitment on the part of the cell towards an alternative vegetative developmental sequence.

We thank C. R. Cooper for determining the reversibility of cycloheximide inhibition, J. R. Pringle for useful discussions concerning the relevance of the downshift experiments and cell cycle blocks, and D. Finkelstein and D. Deters for helpful comments and for critically reviewing the manuscript. The assistance of Susan Crossland in helping prepare the typescript is also gratefully acknowledged. C. W. J. was a predoctoral fellow of the National Science Foundation and the Mycological Society of America. 


\section{REFERENCES}

COOPER, C. R., HARRIS, J. L., JACOBS, C. W. \& SzaniszLo, P. J. (1984). Effects of polyoxin AL on cellular development in Wangiella dermatitidis. Experimental Mloology 8, 349-363.

DEKLOET, S. R. (1966). The effect of cycloheximide on the synthesis of ribonucleic acid in Saccharomyces carlsbergensis. Biohitmical Journal 99, 566-581.

Elford, H. L. (1968). Effect of hydroxyurea on ribonucleotide reductise. Biochemical and Biophysical Research Communicutions 33, 129-135.

Fiala, E. S. \& Davis, F. F. (1965). Preferential inhibition of synthesis and methylation of ribosomal RNA in Neurospora crassa by Actidione. Biochemical and Biophysical Re'search Communications 18, 115 118.

Fukuhara, H. (1965). RNA synthesis in yeast in the presence of cycloheximide. Biochemical and Biophysical Research Communicutions 18, 297-301.

Haidle, C. W. \& STORCK, R. (1966). Inhibition by cycloheximide of protein and RNA synthesis in Mucor rouxii. Bioche'mical and Biophysical Research Communications 22, 175-180.

Horgen, P. A. \& Griffin, D. H. (1971). Specific inhibitors of the three RNA polymerases from the aquatic fungus Blastocladiella emersonii. Proceedings of the National Acalemy of Sciences of the United States of America 68, 338-341.

JaCOBS, C. W. \& Szaniszlo, P. J. (1982). Microtubule function and its relation to cellular development and the yeast cell cycle in Wangiella dermatitidis. Archives of Microbiology 133, 155-161.

Jacobs, C. W. \& Szaniszlo, P. J. (1985). Altered development in a temperature-sensitive morphological mutant of Wangiella dermatitidis. Mycologia 77, $142-148$

MCGinnis, M. R. (1983). Chromomycosis and phaeohyphomycosis: new concepts, diagnosis, and mycology. Journal of the American Academy of Dermatology 8, 1-16.

Nishimura, K. \& Miyaji, M. (1983). Defense mechanism of mice against Exophiala dermatitidis infection. Mycopathologia 81, 9-21.
Oujezdsky, K. B., Grove, S. N. \& Szaniszlo, P. J. (1973). Morphological and structural changes during yeast-to-mold conversion of Phialophora dermatitidis. Journal of Bacteriology 113, 468-477.

Roberts, R. L. \& Szaniszlo, P. J. (1978). Temperature-sensitive multicellular mutants of Wangiella dermatitidis. Journal of Bacteriology 135, 622-632.

Roberts, R. L. \& Szaniszlo, P. J. (1980). Yeast-phase cell cycle of Wangiella dermatitidis. Journal of Bacteriology 144, 721-731.

Roberts, R. L., Lo, R. J. \& Szaniszlo, P. J. (1979). Nuclear division in temperature-sensitive multicellular mutants of Wangiella dermatitidis. Journal of Bacteriology 137, 1456-1458.

Roberts, R. L., Lo, R. J. \& Szaniszlo, P. J. (1980). Induction of synchronous growth in the yeast phase of Wangiella dermatitidis. Journal of Bacteriology 141, 981-984.

Szaniszlo, P. J., Hseih, P. H. \& Marlowe, J. D. (1976). Induction and ultrastructure of the multicellular (sclerotic) morphology in Phialophora dermatitidis. Mycologia 68, 117-130.

Szaniszlo, P. J., Geis, P. A., Jacobs, C. W., CoOper, C. R. \& Harris, J. L. (1983a). Cell wall changes associated with yeast-to-multicellular form conversion in Wangiella dermatitidis. In Microbiology 1983, pp. 239-244. Edited by D. Schlessinger. Washington, DC: American Society for Microbiology.

Szaniszlo, P. J., JACOBS, C. W. \& GeIs, P. A. (1983b). Dimorphism: morphological and biochemical aspects: In Fungi Pathogenic for Humans and Animals (Part A): Biology, pp. 323-436. Edited by D. W. Howard. New York: Marcel Dekker.

TABER, R. L. \& VINCENT, W. S. (1969). Effects of cycloheximide on ribosomal RNA synthesis in yeast. Biochemical and Biophysical Research Communications 34, 488-494.

Timberlake, W. E. \& Griffin, D. H. (1974). Differential effects of cycloheximide and other inhibitors of protein synthesis on in vivo ribosomal RNA synthesis in Achlya ambisexualis. Biochimica et biophysica acta 353, 248-252. 